\title{
APPLICATIONS OF AAS AND DIATOM ANALYSIS AND STYLISTIC STUDIES OF FINNISH SUBNEOLITHIC POTTERY
}

\author{
PENTTI ALHONEN, JYRI KOKKONEN, HEIKKI MATISKAINEN \\ and ANTTI VUORINEN
}

\begin{abstract}
ALHONEN, P., KOKKONEN, J., MATISKAINEN, H. and VUORINEN, A.1 1980: Applications of AAS, diatom analysis and stylistic studies on Finnish Subneolithic pottery, Bull. Geol. Soc. Finland 52-2, 193 - 206.

Ten prehistoric Comb Ceramic vessels found near Kotka have been studied with the aid of AAS and diatom analysis. Correspondence between stylistic and decorative groupings show that the variation in the elements determined by AAS is apparently due to the coarse sand temper added to the clay during the actual manufacture of the vessels. The composition of the Pit and Comb Ware vessel differs considerably from the others, the ornamentation suggesting East Karelian provenience. The diatom flora in the clay material of the vessels corresponds to the stylistic classification. The raw material was apparently either glacial or fresh water clay, whose technical properties correspond to those of clay in modern tile production

Alhonen Pentti, University of Helsinki, Department of Geology, Division of Geology and Palaeontology, Snellmaninkatu 5, SF-00170 Helsinki 17, Finland.

Kokkonen Jyri, University of Helsinki, Department of Archaeology, Nervanderinkatu 13, SF-00101 Helsinki 10, Finland.

Matiskainen Heikki, Department of Geology, Division of Geology and Palaeontology, Snellmaninkatu 5, SF-00170 Helsinki 17, Finland. Vuorinen Antti, University of Helsinki, Department of Geology, Division of Geology and Mineralogy, Snellmaninkatu 5, SF-00170 Helsinki 17, Finland.
\end{abstract}

\section{Introduction}

The sherds studied in this paper are from the Comb Ceramic period dwelling site at Niskasuo in the former parish of Kymi (muncipality of Kotka) in SE Finland (3024 07, $\mathrm{x}=671973, \mathrm{y}=48903)$. The site is located at the edge of a bog on the eastern shore of the Kymi river about $15 \mathrm{~km}$ NNW of Kotka at an elevation of c $20 \mathrm{~m}$ a.s.1. The terrain is mainly pine forest on sandy soil sloping gently to the SW. The site is bordered by open bedrock on one side and marshy ground on the other. Visible features are three possibly prehistoric hut-floors and a present-day sandpit. Surveys indicate a site area of c $350 \mathrm{~m} \times 50 \mathrm{~m}$ running SE.

\footnotetext{
1 in alphabetical order
}

In 1966 Dr. Ville Luho conducted excavations over c $220 \mathrm{~m}^{2}$ in the area adjacent to the sandpit in the central part of the site. Luho's finds consisted of ceramics, debris and artefacts of stone, quartz and flint as well as fragments of clay idols, amber and burnt bone. Luho's ceramic material has been further studied by Jyri Kokkonen (1978). Analyses of the bone material carried out by Mikael Fortelius in conjunction with this study indicated seal-hunting activities. Field phosphate survey and levelling performed by Kokkonen suggest a lower limit for the site at $20-20.5 \mathrm{~m}$ a.s.1., which corresponds to observations obtained on Comb Ceramic period II sites in the region. 


\section{The ceramic material}

The sherds (c 17200 in number) were from approximately $190( \pm 10)$ vessels, of which 106 were in such a state of preservation as to facilitate stylistic description and analysis. The vessels were defined according to rim sherds; complete reconstructions were not aimed at. Most of the sherds (98 vessels) corresponds to the stylistic criteria of the "Typical Comb Ceramic», particularly its earlier phase (hence Ka II: 1) as defined by Äyräpää (1930, 1955). At least 10 vessels show features of Äyräpää's »Hochstil» with bordered geometric designs executed with comb stamps. Three vessels are from an earlier phase of the Late Comb Ceramic (hence Ka III: 1) as defined by Äyräpää (1925, 1930). The Pit and Comb vessel corresponds to East Karelian finds and is the westernmost occurrence of the style found to date (cf. Pankrusev 1964, Brjussov 1957). The rest of the material could not be identified with reference to present classifications.

The Ka II: 1 vessels from Niskasuo have close parallels in many Comb Ceramic finds in the Kymi region and in certain details in finds of Ka II: 1 and 2 in SE Finland in general. Various ornamental details of the Niskasuo vessels can be shown to occur in Ka II finds from Häyrynmäki in Viipuri, the Kaukola sites on the Karelian isthmus and finds from the Leningrad region (Pälsi 1915, Gurina 1958). The present material is probably part of a broad Comb Ceramic tradition that thrived in the coastal region of SE Finland and in the eastern part of the Gulf of Finland.

In Kokkonen's study the Ka II: 1 vessels were further classified taking the predominant decorative motif of the outer surface as the main criterium. The following main groups were established:

A. Vessels with chevron-like and zig-zag designs executed with comb stamps, designs of either hatched and bordered fields or of single lines.
B. Vessels with rectangular, rhomboid or lozenge-like designs of comb stamps.

C. Vessels with horizontal rows of comb stamp impressions.

In addition there were two vessels with vertical chevron designs resembling a fishspine (group D). The Ka II: 1 material which did not correspond to the criteria for the above was designated $\gg$ Other». The number of vessels in the main groups is as follows: A 23, B 26 and C 39. There is a striking similarity between the main groups and the material that did not facilitate vessel identification in the rim forms and the ornamentation of the upper part of the rim, and the designs of the first two ornamental zones. The distinguishing motif generally occurs first in the third ornamental zone and is then repeated along the outer surface of the vessel (Kokkonen 1978).

\section{The sample vessels}

The sample vessels in this study were selected as follows (numbering according to Kokkonen 1978):

Ka II: 1

Group A:

Group B:

Group C:

Ka III: 1

"Other»:

Pit and Comb

Ware:

Vessels 42 and 61, Fig. 1. Vessels 37 and 93, Fig. 2. Vessels 19 and 57, Fig. 3. Vessels 13 and 74, Fig. 4. Vessel 71, Fig. 5.

Vessel 14, Fig. 5.

The main criterium of selection was the availability of sherds that could be destroyed in the analyses as well as the ready identifiability of the sample sherds. One of the main points of interest was whether classifications on the basis of stylistic similarity could be confirmed by analyses on the actual raw material of the vessels.

\section{Stylistic analysis}

In the sample at hand the $\mathrm{Ka}$ III vessels differ most clearly from the others; the rim 

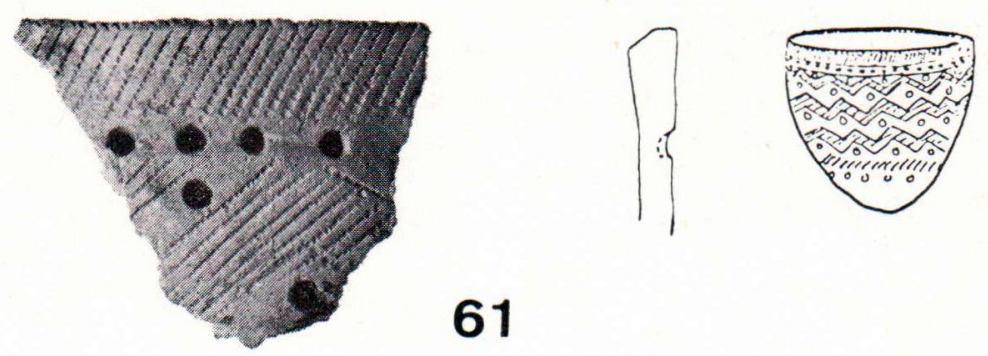

Fig. 1. Sample vessels of the Group A. (All fotos by Tapio Seger).
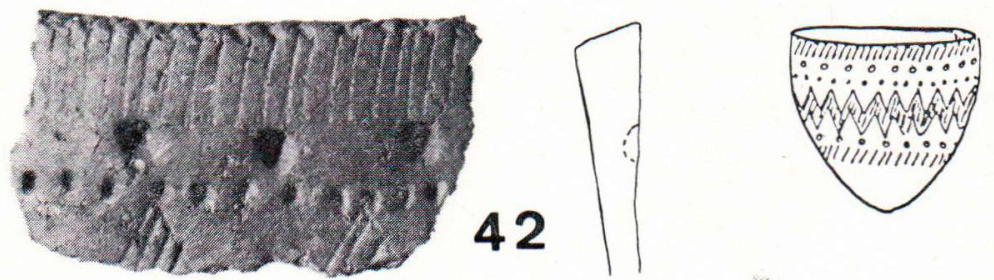

is straight and unaccentuated with small, possibly finger, impressions and a decoration of pit impressions on the outer edge. The outer surface bears a decoration consisting of pit impressions placed sparsely in rows. The Pit and Comb vessel differs stylistically only with respect to the predominance of deep pits on the outer surface; both vessel and rim forms and the comb stamp ornaments on top of the rim and on the outer edge are similar to those in the $\mathrm{Ka}$ II vessels. The sample of $\mathrm{Ka}$ II »Other», vessel 71, is interesting in that, after the first two ornamental zones, which are similar to those in the main groups, the
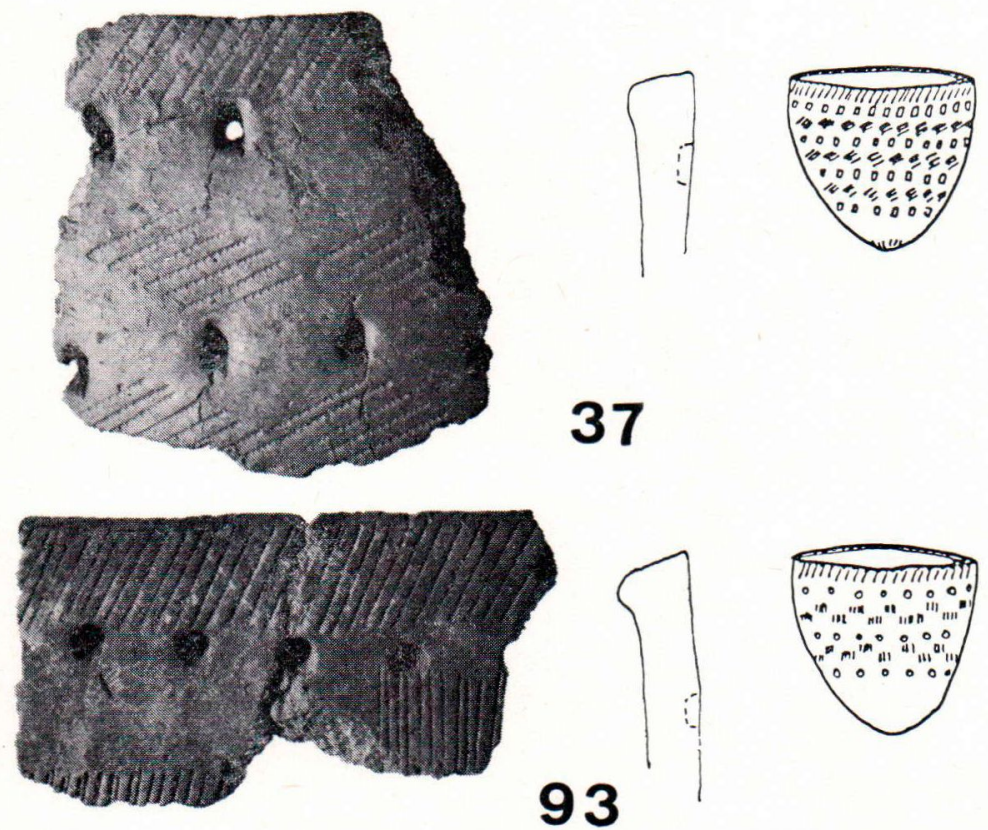

Fig. 2. Sample vessels of the Group B. 


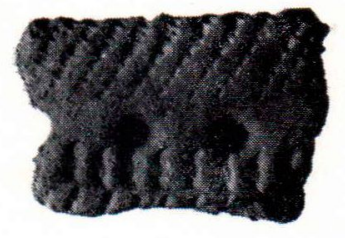

19
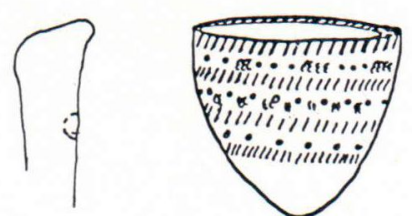

outer surface is sparsely decorated with groups of three pits. In an unpublished study, Luho has suggested that this ornamentation is chronologically comparable to $\mathrm{Ka}$ III (Luho 1959).

The $\mathrm{Ka}$ II vessels are similar chiefly with respect to the ornamentation of the upper parts of the rims. All have comb stamps on top of the rim in either single or double rows.

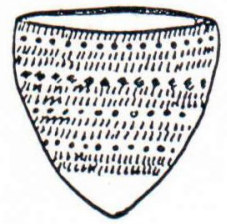

Fig. 3. Sample vessels of the Group C.
The first two ornamental zones are practically identical in nearly all of the $\mathrm{Ka}$ II vessels. The main differences are in the actual decorative elements and in minor details of composition, e.g. the addition of rows of short impressions and identations and impressions on the outer edge. Variation also occurs in the thickness of the actual rim and in the possible accentuation of the form. Vessel 71,
Fig. 4. Sample vessels of the Group Ka III.

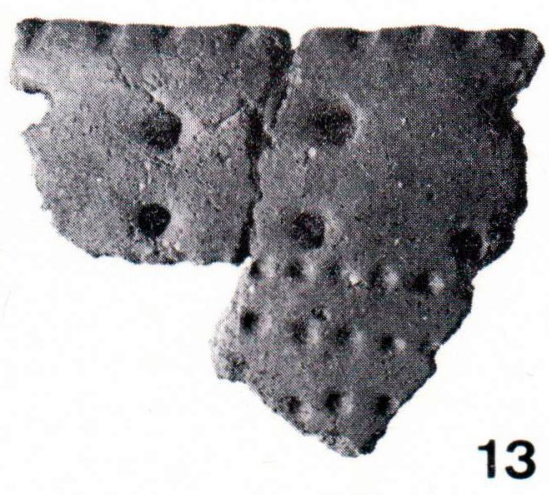

13

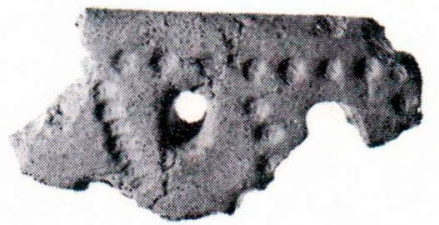

74
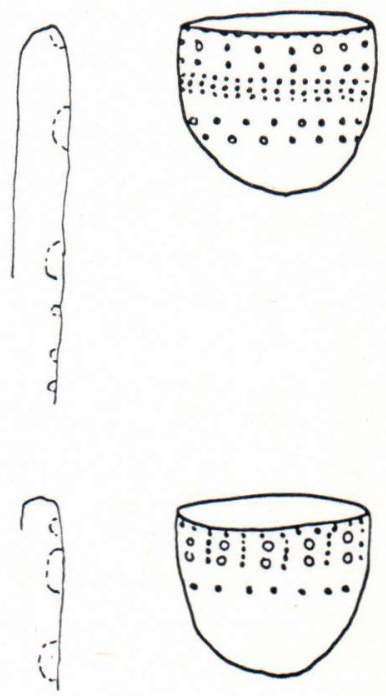

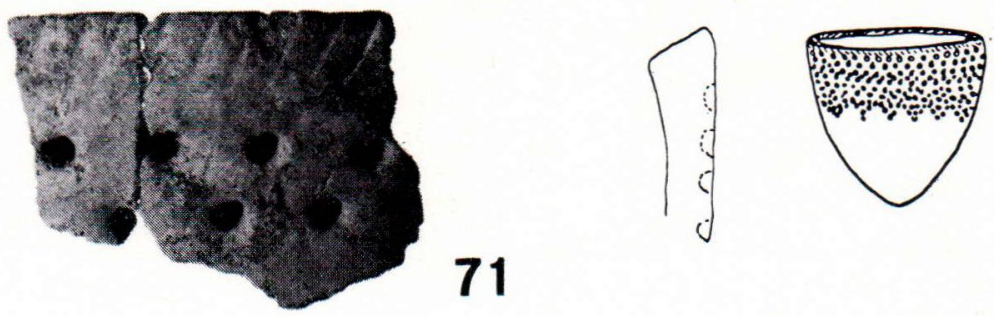

Fig. 5. Sample vessels of

the Group »Other» (71) and the vessel of the Pit and Comb Ware (14).
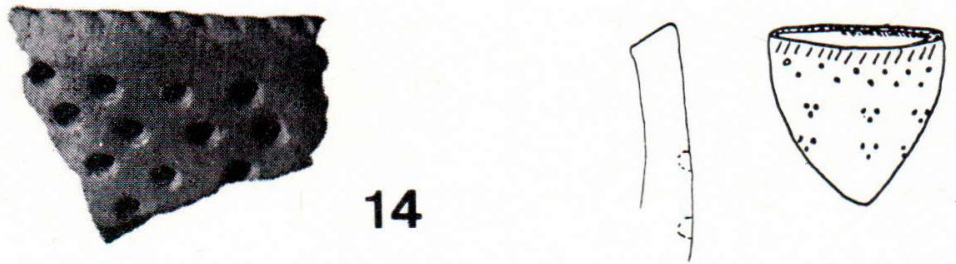

however, shows that the actual form of the rim can vary in the same vessel.

To illustrate the stylistic similarity/dissimilarity between the samples a numerical analysis was carried out with the vessels as O.T.U:s (cf. Sokal \& Sneath 1963) and the following stylistic features as distinguishing factors: vessel size, rim shape, ornamentation of first ornamental zone, ornamentation of second ornamental zone and ornamentation of third (distinguishing) ornamental zone. The factors were subdivided into 42 alternatives and the degree of similarity was defined on the basis of common features and given as Jaccard's coefficient (Sokal \& Sneath 1963).
The results of the comparisons are given in matrix form indicating the degree of similarity between each vessel pair at the conjunction of the rows and lines (Table 1). The matrix is ordered in such a way that the vessels of high mutual similarity are placed close to one another on the line and the clustering can be seen in the matrix itself. This is possible only with small number of samples; with larger numbers this cannot be done by hand. In the comparison the ornamentation of the third decorative zone was stressed as it had revealed itself to be a distinguishing factor. The similarity matrix shows clearly the clustering of the vessels of groups A, B and C; the stressing of the dis-

Table 1. Stylistic similarity between sample vessels.

\begin{tabular}{|c|c|c|c|c|c|c|c|c|c|c|}
\hline Vessels & 37 & 57 & 19 & 42 & 93 & 61 & 71 & 74 & 14 & 13 \\
\hline 37 & 1 & 0.71 & 0.57 & 0.57 & 0.71 & 0.28 & 0.42 & 0.14 & 0.28 & 0 \\
\hline 57 & & 1 & 0.85 & 0.57 & 0.42 & 0.28 & 0.42 & 0.14 & 0.28 & 0 \\
\hline 19 & & & 1 & 0.42 & 0.42 & 0.28 & 0.42 & 0.14 & 0.28 & 0 \\
\hline 42 & & & & 1 & 0.28 & 0.57 & 0.28 & 0.14 & 0.14 & 0 \\
\hline 93 & & & & & 1 & 0.42 & 0.28 & 0 & 0.28 & 0 \\
\hline 61 & & & & & & 1 & 0.14 & 0 & 0.28 & 0 \\
\hline 71 & & & & & & & 1 & 0.28 & 0.14 & 0.14 \\
\hline 74 & & & & & & & & 1 & 0 & 0.57 \\
\hline 14 & & & & & & & & & 1 & 0 \\
\hline 13 & & & & & & & & & & 1 \\
\hline
\end{tabular}




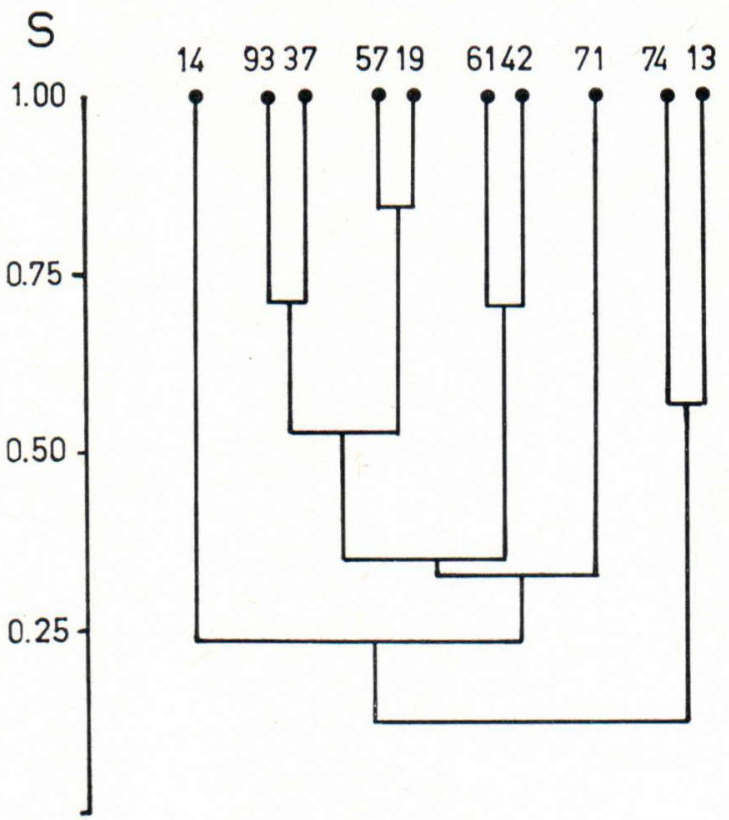

Fig. 6. Dendrogram indicating stylistic similarity between sample vessels (cf. Table 1). $\mathrm{S}=$ degree of similarity.

tinguishing motif gives the Pit and Comb vessel a lower score in this respect.

The results of the numerical comparison can further be shown in the form of a dendrogram (Fig. 6). Although the figure is a schematic representation of a multidimensional situation arrived at by a heuristic method, it serves to illustrate the nature of the sample studied and to demonstrate in graphic manner the similarity/dissimilarity between the O.T.U:s. The figure shows the clusters that are identifiable in the sample vessels and the mean level of similarity at which the clusters and single vessels can be linked to one another. The diagram shows the high level of similarity between the vessels of groups A, B and C, the links of the sample of $\mathrm{Ka}$ »Other» and the Pit and Comb vessel and the strong dissimilarity between the $\mathrm{Ka}$ III vessels and the rest of the samples.

\section{Atomic absorption spectrometric analysis}

In the study on the physical properties of prehistoric artefacts, especially ceramics, the geochemical and physical methods presently in use have been successfully applied. The most popular appear to be X-ray fluorescence and neutron activation analysis (cf. Pearlman and Asaro 1969; Stos-Fertner, Hedges and Evely 1979). Other methods that have been used in archaeology are X-ray powder diffraction, Moessbauer spectroscopy, differential thermal analysis and AAS, (Tite 1972; Shepard 1968; Bomgardner and Hatcher 1979; Hughes, Cowell and Craddock 1976). In this study it has been attempted with the help of AAS to define the division of elements in the sherds and to test the observed similarity between elements and the groups of vessels obtained on criteria of style and form.

The sherds were crushed carefully in an agate mortar to separate the fine clayey iron oxide material from the coarser silicate mineral material (quartz, feldspar, etc.) to which the iron oxides had affixed themselves. The samples were then sieved and fractioned on paper; the fractions obtained were $<0.2 \mathrm{~mm}$ and $>0.2 \mathrm{~mm}$. The coarser fraction also contained clayey aggregates. The Fe oxides and the elements adsorbed by the fine matter were dissolved from the samples in $\mathrm{HCl}+$ $\mathrm{HNO}_{3}$ (+ some $\mathrm{HClO}_{4}$ to retain oxidizing conditions) on a sand bath in teflon dishes, (on the amounts of dissolved material see Table 2). The solutions were analyzed with a PERKIN-ELMER mod. 403 atomic absorption spectrometer. $\mathrm{Hg}$ was determined by the cold-gas method (Table 3a,b).

The colour of the coarse matter solution varied in relation to the humic concentration. The humic matter is generally determined by extraction with $0.5 \% \mathrm{NaOH}$. An identical result, however is achieved with $\mathrm{HCl}$ extraction (Schnitzer \& Skinner 1968) and the mild oxidation does not affect the humic 
Table 2. Amounts of dissolved matter.

\begin{tabular}{ccc}
\hline Vessels & Fine $\%$ & Coarse $\%$ \\
\hline & & \\
42 & 6.34 & 27.24 \\
61 & 28.04 & 20.40 \\
37 & 21.52 & 23.32 \\
93 & 11.71 & 18.83 \\
19 & 40.84 & 26.27 \\
57 & 15.94 & 17.19 \\
71 & 15.76 & 23.13 \\
13 & 10.98 & 17.83 \\
74 & 44.91 & 20.48 \\
14 & 53.58 & 25.60 \\
\hline Corr/Fe & 754 & 897 \\
\hline
\end{tabular}

compounds very much. These occur together with $\mathrm{Fe}$ oxides. The absorbances of the humic compounds in the solution were measured by spectrometer at wavelengths $430,490,550,600$ and $680 \mathrm{~nm}$, and the slope coefficient of 430 and 550 were calculated. These reflect the degree of polymerisation of the humic compounds - the greater the value of the slope, the smaller the amount of polymerized compounds. The values of the slope coefficient also correlate with the concentration of humic compounds, and it was from these that the relative humic units were calculated taking into account the corrections caused by the colour of the Fe concentration. The samples were then weighed (Table 4).

To establish which elements were related to the various fractions, correlation coefficients were calculated for iron in relation to the dissolved matter and the relative humic concentration in the coarse fraction. For other elements, correlation coefficients were calculated in relation to iron in both

Table 3 a. Element contents.

\begin{tabular}{|c|c|c|c|c|c|c|c|c|c|c|}
\hline $\begin{array}{l}\text { COARSE } \\
\text { Vessels }\end{array}$ & $\begin{array}{r}\text { FRACTION } \\
\text { Fe } \\
0 \%\end{array}$ & $\begin{array}{l}\text { Al } \\
0 \% 0\end{array}$ & $\begin{array}{l}\mathrm{Mn} \\
\mathrm{ppm}\end{array}$ & $\begin{array}{c}\mathrm{Zn} \\
\mathrm{ppm}\end{array}$ & $\begin{array}{c}\mathrm{Cu} \\
\mathrm{ppm}\end{array}$ & $\begin{array}{l}\mathrm{Pb} \\
\mathrm{ppm}\end{array}$ & $\begin{array}{l}\text { Co } \\
\text { ppm }\end{array}$ & $\begin{array}{c}\mathrm{Ni} \\
\mathrm{ppm}\end{array}$ & $\begin{array}{c}\mathrm{Cd} \\
\mathrm{ppm}\end{array}$ & $\begin{array}{l}\mathrm{Hg} \\
\mathrm{ppb}\end{array}$ \\
\hline 42 & 5.08 & 4.49 & 541 & 64.5 & 20.3 & 18.2 & 19.3 & 41.4 & 0.4 & 14 \\
\hline 61 & 3.59 & 3.25 & 415 & 57.8 & 15.7 & 16.9 & 12.3 & 24.4 & 0.4 & 7 \\
\hline 37 & 4.91 & 4.11 & 347 & 53.8 & 22.8 & 17.2 & 18.6 & 37.2 & 0.3 & 32 \\
\hline 93 & 3.38 & 3.00 & 583 & 45.4 & 17.1 & 16.0 & 14.4 & 22.8 & 0.6 & 10 \\
\hline 19 & 4.86 & 4.61 & 1300 & 85.6 & 18.9 & 23.5 & 21.1 & 38.2 & 0.4 & 5 \\
\hline 57 & 3.66 & 3.33 & 303 & 61.0 & 17.3 & 14.7 & 13.6 & 28.1 & 0.3 & 4 \\
\hline 71 & 4.74 & 3.54 & 956 & 52.6 & 11.6 & 23.7 & 17.5 & 29.9 & 0.3 & 9 \\
\hline 13 & 3.77 & 3.11 & 615 & 41.5 & 13.4 & 13.8 & 16.8 & 30.9 & 0.4 & 17 \\
\hline 74 & 4.42 & 3.27 & 593 & 48.6 & 9.7 & 20.8 & 15.2 & 29.9 & 0.3 & 10 \\
\hline 14 & 5.21 & 4.70 & 681 & 152.0 & 20.0 & 29.9 & 23.0 & 42.7 & 0.3 & 1 \\
\hline
\end{tabular}

Table 3 b. Element contents.

\begin{tabular}{|c|c|c|c|c|c|c|c|c|c|c|}
\hline $\begin{array}{l}\text { FINE F } \\
\text { Vessels }\end{array}$ & $\begin{array}{l}\mathrm{Fe} \\
0 \%\end{array}$ & $\begin{array}{l}\mathrm{Al} \\
0 \%\end{array}$ & $\begin{array}{l}\mathrm{Mn} \\
\mathrm{ppm}\end{array}$ & $\begin{array}{c}\mathrm{Zn} \\
\mathrm{ppm}\end{array}$ & $\begin{array}{c}\mathrm{Cu} \\
\mathrm{ppm}\end{array}$ & $\begin{array}{c}\mathrm{Pb} \\
\mathrm{ppm}\end{array}$ & $\begin{array}{c}\text { Co } \\
\text { ppm }\end{array}$ & $\begin{array}{c}\mathrm{Ni} \\
\text { ppm }\end{array}$ & $\begin{array}{c}\mathrm{Cd} \\
\mathrm{ppm}\end{array}$ & $\begin{array}{l}\mathrm{Hg} \\
\mathrm{ppb}\end{array}$ \\
\hline 42 & 6.12 & 6.51 & 530 & 56.2 & 33.6 & 23.0 & 19.2 & 70.0 & 0.3 & 14 \\
\hline 61 & 4.77 & 4.62 & 314 & 47.4 & 20.0 & 15.0 & 12.1 & 34.3 & 0.3 & 15 \\
\hline 37 & 5.53 & 5.32 & 254 & 40.0 & 22.0 & 14.0 & 17.0 & 11.4 & 0.3 & 21 \\
\hline 93 & 5.12 & 5.60 & 450 & 50.0 & 30.0 & 15.0 & 19.0 & 35.1 & 0.4 & 32 \\
\hline 19 & 4.95 & 4.87 & 1000 & 56.3 & 16.4 & 20.0 & 16.6 & 42.5 & 0.6 & 12 \\
\hline 57 & 5.00 & 4.89 & 357 & 62.0 & 23.0 & 15.0 & 15.0 & 42.3 & 0.3 & 10 \\
\hline 71 & 5.33 & 4.52 & 690 & 36.1 & 12.4 & 26.0 & 15.1 & 32.1 & 0.3 & 13 \\
\hline 13 & 6.30 & 6.30 & 690 & 44.0 & 28.4 & 21.0 & 25.0 & 62.5 & 0.5 & 26 \\
\hline 74 & 5.67 & 4.11 & 430 & 33.2 & 10.4 & 24.0 & 14.0 & 34.1 & 0.3 & 6 \\
\hline 14 & 4.76 & 4.54 & 450 & 103.0 & 20.0 & 12.0 & 17.0 & 42.2 & 0.2 & 11 \\
\hline
\end{tabular}


Table 4. Relative contents of humic substance.

\begin{tabular}{cr}
\hline \multicolumn{2}{c}{ »Humic substance» } \\
Vessels & units \\
& \\
\hline & \\
62 & 457.4 \\
31 & 167.6 \\
93 & 360.2 \\
19 & 158.5 \\
57 & 277.8 \\
71 & 116.7 \\
13 & 295.7 \\
74 & 263.0 \\
14 & 479.1 \\
\end{tabular}

the fine and coarse fractions and in relation to the humic units (Table 5). $\mathrm{Zn}$ and $\mathrm{Cu}$ correlate strongly with the coarse fraction, $\mathrm{Cd}$ with the fine fraction and $\mathrm{Hg}$ and $\mathrm{Fe}$ with the humic fraction. The correlation coefficients of the elements in both the fine and coarse fractions are given in Tables $6 \mathrm{a}$ and $\mathrm{b}$.

The enrichment coefficients in fine/coarse fractions were in the following order (Table 7) $\mathrm{Cu}>\mathrm{Fe} \geqslant \mathrm{Ni}>\mathrm{Co} \sim \mathrm{Pb}>\mathrm{Zn} \sim \mathrm{Mn}$, which corresponds to the enrichment coefficients of elements in the fine fraction as compared to the coarse fraction in various soil materials from South Sweden except with respect to $\mathrm{Zn}: \mathrm{Cu}>\mathrm{Ni}>\mathrm{Zn} \geqslant \mathrm{Cr}>\mathrm{Co}>$
Table 5. Correlations/Fe in different fractions.

\begin{tabular}{lccr}
\hline & COARSE & FINE & »HUMIC» \\
\hline $\mathrm{Mn}$ & 391 & 121 & 101 \\
$\mathrm{Co}$ & 867 & 670 & 205 \\
$\mathrm{Ni}$ & 928 & 489 & 360 \\
$\mathrm{Zn}$ & 553 & -509 & -307 \\
$\mathrm{Cu}$ & 365 & 60 & -160 \\
$\mathrm{~Pb}$ & 720 & 584 & 26 \\
$\mathrm{Cd}$ & -522 & 180 & -243 \\
$\mathrm{Hg}$ & 335 & 675 & 405 \\
$\mathrm{Al}$ & 878 & & 209 \\
& CORRELATIONS/SOLUBLE & \\
$\mathrm{Fe}$ & 879 & 754 & 583 \\
\hline
\end{tabular}

$\mathrm{Cd}>\mathrm{Pb}$ (Andersson 1979). Thus owing to similar climate conditions the materials may derived from similar soil.

The heavy metal concentrations enriched in the fine material and $\mathrm{Fe}$ oxides $(\mathrm{Zn}, \mathrm{Cu}$, $\mathrm{Pb}, \mathrm{Co}, \mathrm{Ni}$ ) were calculated to compare the regional concentrations of the areas. The values for vessel 19 and 57 corresponded best to the values of the cluster analysis; vessel 14 differed most from the others (Fig. 8). The correspondence with single element concentrations was best in the fine fraction (Tables 4 and 5).

The main silicate minerals of the coarsest matter in the samples are given in Table 8 .

Table 6 a. Correlations between elements in different fractions.

\begin{tabular}{|c|c|c|c|c|c|c|c|c|c|}
\hline Coarse & $\mathrm{Fe}$ & $\mathrm{Mn}$ & $\mathrm{Co}$ & $\mathrm{Ni}$ & $\mathrm{Zn}$ & $\mathrm{Cu}$ & $\mathrm{Pb}$ & $\mathrm{Cd}$ & $\mathrm{Hg}$ \\
\hline $\mathrm{Fe}$ & 1000 & & & & & & & & \\
\hline Mn & 391 & & & & & & & & \\
\hline $\mathrm{Co}$ & 867 & 532 & & & & & & & \\
\hline $\mathrm{Ni}$ & 923 & 275 & 915 & & & & & & \\
\hline $\mathrm{Zn}$ & 558 & 266 & 714 & 653 & & & & & \\
\hline $\mathrm{Cu}$ & 365 & -159 & 468 & 564 & 425 & & & & \\
\hline $\mathrm{Pb}$ & 720 & 571 & 723 & 569 & 807 & 59 & & & \\
\hline $\mathrm{Cd}$ & -522 & 73 & -260 & -415 & -282 & 81 & -372 & & \\
\hline $\mathrm{Hg}$ & 335 & -357 & 329 & 399 & -347 & 439 & -251 & -166 & \\
\hline $\mathrm{Al}$ & 878 & 389 & 889 & 935 & 726 & 662 & 654 & -304 & 202 \\
\hline
\end{tabular}

$\mathrm{Mn}: \mathrm{Pb}>\mathrm{Co}$

$\mathrm{Co}: \mathrm{Ni}>\mathrm{Al}, \mathrm{Fe}, \mathrm{Pb}, \mathrm{Mn}$

$\mathrm{Ni}: \mathrm{Al}, \mathrm{Fe}, \mathrm{Co}, \mathrm{Zn}, \mathrm{Pb}, \mathrm{Cu}$

$\mathrm{Zn}: \mathrm{Pb}, \mathrm{Al}, \mathrm{Co}, \mathrm{Ni}$

$\mathrm{Cu}: \mathrm{Al}, \mathrm{Ni}$
$\mathrm{Pb}: \quad \mathrm{Zn}, \mathrm{Co}, \mathrm{Fe}, \mathrm{Al}, \mathrm{Mn}, \mathrm{Ni}$

$\mathrm{Cd}: \quad-\mathrm{Fe}$

$\mathrm{Hg}$ : -

$\mathrm{Al}$ : $\mathrm{Ni}, \mathrm{Co}, \mathrm{Fe}, \mathrm{Zn}, \mathrm{Cu}, \mathrm{Pb}$

$\mathrm{Fe}$ : $\mathrm{Ni}, \mathrm{Al}, \mathrm{Co}, \mathrm{Pb}, \mathrm{Zn}$ 
Table $6 \mathrm{~b}$. Correlations between elements in different fractions.

\begin{tabular}{|c|c|c|c|c|c|c|c|c|c|}
\hline FINE & $\mathrm{Fe}$ & Mn & Co & $\mathrm{Ni}$ & $\mathrm{Zn}$ & $\mathrm{Cu}$ & $\mathrm{Pb}$ & $\mathrm{Cd}$ & $\mathrm{Hg}$ \\
\hline $\mathrm{Fe}$ & 1000 & & & & & & & & \\
\hline $\mathrm{Mn}$ & 121 & & & & & & & & \\
\hline Co & 670 & 328 & & & & & & & \\
\hline $\mathrm{Ni}$ & 489 & 402 & 559 & & & & & & \\
\hline $\mathrm{Zn}$ & -509 & -29 & 45 & 240 & & & & & \\
\hline $\mathrm{Cu}$ & -60 & -356 & 650 & 541 & 185 & & & & \\
\hline $\mathrm{Pb}$ & 584 & 527 & 101 & 345 & -579 & -266 & & & \\
\hline $\mathrm{Cd}$ & 180 & 761 & 446 & 244 & -60 & 99 & -191 & & \\
\hline $\mathrm{Hg}$ & 238 & -48 & 635 & 254 & -191 & 636 & -254 & 343 & \\
\hline $\mathrm{Al}$ & 675 & 112 & 813 & 612 & -64 & 903 & 72 & 312 & 621 \\
\hline $\mathrm{Fe}:$ & $\mathrm{Al}>\mathrm{Co}>\mathrm{Pb}$ & $(-\mathrm{Zn})$ & & $\mathrm{Cu}:$ & $\mathrm{Al}>\mathrm{C}$ & $\mathrm{Hg}>$ & & & \\
\hline Mn: & & & & $\mathrm{Pb}$ : & $\mathrm{Fe}>\mathrm{I}$ & $(-\mathrm{Zn})$ & & & \\
\hline Co: & $\mathrm{Al}>\mathrm{Fe}>\mathrm{Cu}$ & $>\mathrm{Hg}>\mathrm{Ni}$ & & Cd: & $\mathrm{Mn}$ & & & & \\
\hline $\mathrm{Ni}:$ & $\mathrm{Al}>\mathrm{Co}>\mathrm{Cl}$ & & & $\mathrm{Hg}$ : & $\mathrm{Cu} \geqslant \mathrm{c}$ & $>\mathrm{Al}$ & & & \\
\hline $\mathrm{Zn}:$ & $-\mathrm{Pb}>-\mathrm{Fe}$ & & & $\mathrm{Al}:$ & $\mathrm{Cu}>\mathrm{C}$ & $>\mathrm{Fe}>$ & $\geqslant \mathrm{Ni}$ & & \\
\hline
\end{tabular}

The results suggest that the materials of the vessels classified according to features of ornament and form differ from each other except in vessels 19 and 57 (group C).

\section{Diatoms in sherd samples}

Diatom analysis is especially popular in Finland for studying the raw material of prehistoric clay vessels (pioneering studies, e.g. Edgren 1966, 1970, also Foged 1968, Alhonen and Väkeväinen 1980, in print). The starting point of these studies has been the varying saline ecological requirements of diatoms (Diatomae). When preserved, diatoms indicate the formative environment of the clay layers in question. In Finland these can be connected to the geological history of the development of the Baltic, the phases of which have been determined from series of layers with the help of diatom stratigraphy. Being well known, they need not be given here. Some typical diatom flora have been reported by Eronen (1974) and by Ignatius \& Tynni (1978).

About $8-10 \mathrm{~g}$ of the sherds studied were crushed in a mortar. The pulverized matter was then treated in a routine manner with $30 \%$ hydrogen peroxide (e.g. Alhonen 1967, p. 6). Matter hindering the determination of the diatoms was suspended and decanted as thoroughly as possible so that the whole

Table 7. Enrichment coefficients in FINE/COARSE fractions.

\begin{tabular}{|c|c|c|c|c|c|c|c|c|c|c|}
\hline Vessels & $\mathrm{Fe}$ & $\mathrm{Al}$ & $\mathrm{Mn}$ & $\mathrm{Zn}$ & $\mathrm{Cu}$ & $\mathrm{Pb}$ & $\mathrm{Co}$ & $\mathrm{Ni}$ & $\mathrm{Cd}$ & $\mathrm{Hg}$ \\
\hline 42 & 1.20 & 1.45 & 0.98 & 0.87 & 1.70 & 1.26 & 0.99 & 1.64 & 0.75 & 1.00 \\
\hline 61 & 1.33 & 1.42 & 0.76 & 0.82 & 1.68 & 0.89 & 0.98 & 1.41 & 0.75 & 2.14 \\
\hline 37 & 1.23 & 1.29 & 0.73 & 0.74 & 1.10 & 0.82 & 0.91 & 0.30 & 1.00 & 0.66 \\
\hline 93 & 1.51 & 1.87 & 0.77 & 1.10 & 2.16 & 0.94 & 1.32 & 1.54 & 0.67 & 3.20 \\
\hline 19 & 1.02 & 1.06 & 0.77 & 0.66 & 1.11 & 0.85 & 0.79 & 1.11 & 1.50 & 2.40 \\
\hline 57 & 1.37 & 1.47 & 1.18 & 1.02 & 1.68 & 1.02 & 1.10 & 1.50 & 1.00 & 2.50 \\
\hline 71 & 1.12 & 1.29 & 0.72 & 0.68 & 1.27 & 1.10 & 0.86 & 1.07 & 1.00 & 1.44 \\
\hline 13 & 1.67 & 2.03 & 1.12 & 1.06 & 2.12 & 1.52 & 1.49 & 2.02 & 1.25 & 1.53 \\
\hline 74 & 1.28 & 1.26 & 0.74 & 0.68 & 1.20 & 1.15 & 0.92 & 1.14 & 1.00 & 0.60 \\
\hline 14 & 0.91 & 0.97 & 0.66 & 0.68 & 1.33 & 0.40 & 0.74 & 0.99 & 0.67 & $>11$ \\
\hline MEDIAN & 1.23 & 1.41 & 0.84 & 0.83 & 1.54 & 0.99 & 1.01 & 1.27 & 0.96 & 1.55 \\
\hline
\end{tabular}




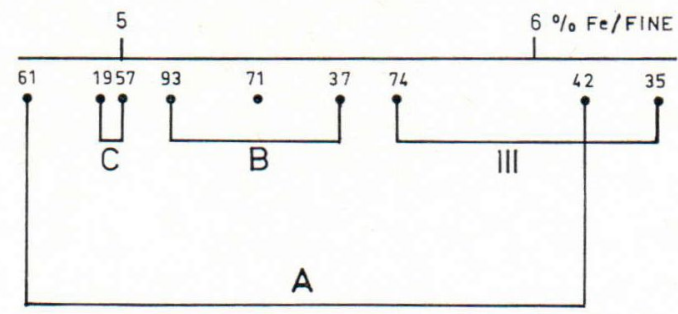

$\Sigma$ FINE
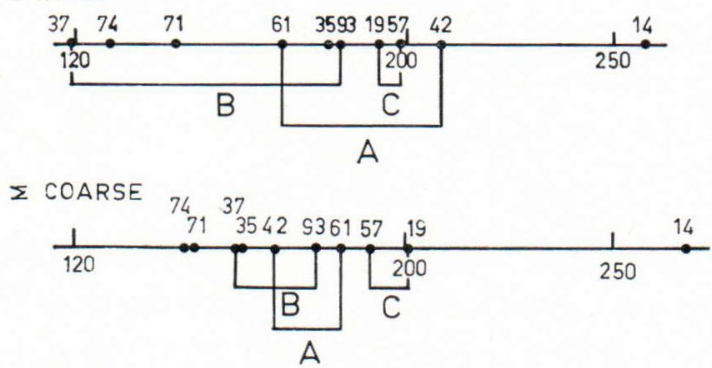

Fig. 8. Heavy metal concentrations and stylistic groups.

matter is represented by two preparations. The preparation slides mounted in "Caedax" were completely investigated microscopically. Each diatom shell and each fragment was determined. The results are given in the numbers of specimens (cf. Foged 1968).

The results of the diatom analysis of the investigated sherds are given in Table 7 . It shows that the species are few in number especially since the numbers in the table also include fragments. Even so, the diatom flora is qualitatively useful with respect to the problem at hand as it contains both clear water forms (e.g. Melosira arenaria and $M$. islandica ssp. helvetica) and marine forms (Campylodiscus echeneis and Cocconeis scutellum). In the history of the Baltic both the above-mentioned Melosira species are characteristic of the Ancylus Lake in general (e.g. Eronen 1974). Campylodiscus echeneis is a poly- or mesohalobic bottom form and Cocconeis scutellum is a marine epiphyte (Miller 1964). These suggest either the Yoldia or Litorina Seas. The former has also been regarded as a typical microfossil of the Yoldia/Ancylus boundary (e.g. Sauramo 1958; also Ignatius \& Tynni 1978, Table 1, p. 9). The sherds are, however, from an area where salt water and brackish water diatoms occur in sediments of the Baltic formed during the period of pollen zone V (Alhonen 1971, Fig. 2). Hence, these clays were formed mainly in the Ancylus Lake. Diatoms indicating salinity would thus be secondarily washed in the transgression of the Ancylus Lake (Eronen 1976) from older layers, namely, those of the Yoldia Sea (Alhonen 1971, pp 7-8).

Taking into account the other fresh water diatoms (Amphora ovalis, Eunotia lunaris, Melosira ambigua, M. granulata var. angustissima, M. italica, Navicula radiosa, Synedra ulna and Tabellaria fenestrata), the diatom analytical interpretation of the origin of the raw material of the vessels being studied is clay deposited in relatively fresh water. In the history of the Baltic this would be mainly Ancylus clay. This is valid as long as the salt water diatoms found in vessels 37, 93, $19,57,71,74$ and 14 do not indicate the primary environment of stratification. If these were primary with respect to their place of growth, the clay of which the vessels

Table 8. Main silicate minerals in the coarsest matter of the samples

\begin{tabular}{|c|c|c|c|c|c|c|}
\hline Vessels & $\mathrm{Q}$ & Plg & $\mathrm{Kfs}$ & D-mica & C-mica & Dark \\
\hline 42 & + & + & & & + & $\therefore$ \\
\hline 61 & + & + & ++ & + & + & + \\
\hline 37 & + & + & ++ & & & \\
\hline 93 & $(+)$ & + & ++ & & & \\
\hline 19 & ++ & + & & ++ & & \\
\hline 57 & + & + & ++ & & & \\
\hline 71 & + & + & ++ & & + & $(+)$ \\
\hline 13 & + & + & ++ & & & \\
\hline 74 & + & + & ++ & & ++ & ++ \\
\hline 14 & + & + & & & & \\
\hline
\end{tabular}

Q quartz; Plg plagioclase; Kfs potassium feldspar; D-mica dark mica; C-mica colourless mica; Dark dark mineral, probably amphibole. 
Table 9. Diatoms found in sherd samples.

\begin{tabular}{|c|c|c|c|c|c|c|c|c|c|c|}
\hline \multirow{2}{*}{ Taxa } & \multicolumn{10}{|c|}{ Vessel } \\
\hline & 42 & 61 & 37 & 93 & 19 & 57 & 71 & 13 & 74 & 14 \\
\hline Amphora ovalis & & & & & & & & & 1 & \\
\hline Campylodiscus echeneis & & & 1 & 1 & 2 & 2 & 1 & & & 2 \\
\hline Cocconeis scutellum & & & & 1 & & & & & 1 & \\
\hline Diploneis sp. & & & & 1 & & & & & & \\
\hline Eunotia lunaris & & & 1 & & & 1 & & & & \\
\hline Melosira ambigua & & & & & & & & & 3 & \\
\hline M. arenaria & 5 & 8 & & & & & & 2 & 1 & \\
\hline M. granulata var. angustissima & & & & & & & & & 2 & \\
\hline M. islandica ssp. helvetica & & & & & & 1 & 4 & 2 & 2 & \\
\hline M. italica & & & & & & & 2 & & & \\
\hline Navicula radiosa & & & & & & & 1 & & & \\
\hline Navicula sp. & & & & 1 & 1 & & & & & \\
\hline Nitzchia sp. & & 1 & & & 1 & & 1 & & 1 & \\
\hline Pinnularia sp. & 1 & & 1 & 1 & & & & 1 & & \\
\hline Synedra ulna & & 2 & & & & & & & & \\
\hline Tabellaria fenestrata & 1 & & & & & & 2 & & & \\
\hline
\end{tabular}

were made could also be from the Yoldia phase.

It is furthermore interesting to note that in vessel 71 in addition to diatoms two cell groups of Pediastrum boryanum were found. This Protococcales green algae, which occurs mainly in lake plankton, may indicate the use of tempers (for example pre-lake mud) in the manufacture of the vessels, as seems to have been the case at Östra Jansmyra in Åland (Alhonen and Väkeväinen 1980).

Few diatom analytical studies of prehistoric clay vessels have so far been carried out in Finland. The raw materials of the Jäkärlä Ware and the Cord Impressed Ware from Perkiö in Hauho (Edgren 1966, 1970) were interpreted as glacial clay, and most of the raw material of the Early Comb Ceramic pottery from Alland seems to have been Ancylus clay (Alhonen and Väkeväinen 1980). The material investigated in this study supports the latter result. It is, however, quite evident that raw material for clay vessels most readily available in the environment of the stone age dwelling sites was taken from the clay in the surface sediments of the terrain.

\section{Concluding remarks}

The stylistic clustering of the vessels is based (cf. p. 194 ff.) on the motifs and variations of the decorated surfaces and the rim forms. The apparent physical properties of the vessels do not affect this classification. One of the most important factors in the AAS results is apparently the coarse sand temper added to the clay in the actual manufacture of the vessels. The main minerals of this matter are shown in Table 6. The correspondence between the $\mathrm{Fe}$ concentrations in the fine matter may be the result of the manufacturing technique which may have included the addition of red ochre to the raw material. Compared with the stylistic analysis a positive result is obtained only within group C. The Pit and Comb Ware vessel (nr. 14) differs considerably in composition from the other vessels and may have been made in East Karelia, a direction of origin that is borne out by the ornamentation.

Despite the sparicity of diatoms in the clay matter, their distribution is in accordance with the stylistic classification. The following diatoms »dominate» the stylistic groups: 
Group $\mathrm{A}=$ Melosira arenaria

Group B = Campylodiscus echeneis

Group C " »

Group III = Melosira islandica ssp helvetica

Furthermore the group »Other» includes the Pediastrum algae, which are lacking in the other samples.

Variations in the stylistic details and forms depend on sites from which clay was obtained at the time of manufacture of the vessels. These changed along with the stylistic tradition. Luho's (1959) assumption that the group »Other» is contemporaneous with $\mathrm{Ka}$ III is supported by the occurrence of $M$. islandica ssp. helvetica in both. Results obtained in different studies (cf. Foged 1968) show that the raw material was either glacial or fresh water clay. Marine flora of the Litorina Sea has not been found so far in any of the vessels studied. This may be attributed to either the salinity or humic consistency of the clay (Okko 1957, Romu 1977, 1978), which made the clay unsuitable for firing.

\section{References}

Alhonen, P. (1967) Palaeolimnological investigations of three inland lakes in south-western Finland. Acta Bot. Fennica 76.

- (1971) The stages of the Baltic Sea as indicated by the diatom stratigraphy. Acta Bot. Fennica 92.

- and Väkeväinen, L. (1980) Diatomanalytical studies on the Early Comb Ceramic sherds from Ahvenanmaa (Aland). Suomen Museo (in print).

Andersson, A. (1974) Tunga metallers förekomst och fördelning i marken. Meddelande 4, Nordic Society for Clay Research.

Bomgardner, D. L. and Hatcher, H. (1979) AASapplications for pottery analysis Proc. int. XIX Symp. in Archaeom. 1979 London.

Brjussov, A. Ja. (1957) Geschichte der neolitischen Stämme in europäischem Teil der USSR. Berlin.

Edgren, T. (1966) Jäkärlä-gruppen. En västfinsk kulturgrupp under yngre stenålder. Suomen muinaismuistoyhdistyksen aikakauskirja 64 .

- (1970) Studier över den snörkeramiska kulturens keramik i Finland. Suomen Muinaismuistoyhdistyksen aikakauskirja 72 .

Eronen, M. (1974) The history of the Litorina Sea and associated Holocene events. Commentat Phys.-Math. 44 (4).

- (1976) A radiocarbon dated Ancylus transgression site in south-eastern Finland. Boreas 5 .
Foged, N. (1968) Diatomeerne i nogle potteskår fra Varanger. Varanger Funnene VI. Tromsø Mus. skr. VII, Hefte VI.

Gurina, N. N. (1958) Die archäologischen Forschungen im Ost-Karelien und im Leningrader Bezirk in den Jahren 1948-1957. Finskt Museum 1958. Helsingfors.

Huges, M. J., Cowell, M. R. and Craddock, P. T. (1976) Atomic absorption techniques in archaeology. Archaeom. 18. Part 1.

Ignatius, H. and Tynni, R. (1978) Itämeren vaiheet ja piilevätutkimus. Publ. of the Dept. of Quaternary Geology, Univ. of Turku. vol 36. Kokkonen, J. (1978) Kymin Niskasuon keramiikkalöydöt. Dept. of Archaeology, Univ. of Helsinki. Stencil 17.

Luho, V. (1959) Unpublished report of excavations carried out at the stone age site at Nikkarinmäki in Kymi. Archive of the National Board of Antiquities and Historical Monuments. Helsinki.

Miller, U. (1964) Diatom floras in the Quaternary of the Göta river valley (western Sweden). Sveriges Geologiska Undersökningar. Ca, 44. Okko, V. (1957) Die Tonvorkomnisse und die Ziegelindustrie in Finland. Fennia 81. Nr 3. Helsinki.

Pankrusev, G. A. (1964) Plemena Karelii v epohi neolita i rannego metalla. Leningrad.

Pearlman, I. and Asaro, F. (1969) Pottery analysis by neutron activation. Archaeom. 11. 
Pälsi, S. (1915) Riukjärven ja Piiskunsalmen kivikautiset asuinpaikat Kaukolassa. Suomen Muinaismuistoyhdistyksen aikakauskirja 28. Helsinki.

Romu, M. (1977) Savien tiiliteknisistä ominaisuuksista Lopella ja Tuusulassa. Publ. of the Dept. of Quaternary Geology Univ. of Turku vol 24.

- (1978) Iisalmen alueen kvartäärisavista ja niiden tiiliteknisistä ominaisuuksista. Publ. of the Dept. of Quaternary Geology Univ. of Tur$\mathrm{ku}$. vol 37 .

Sauramo, M. (1958) Die Geschichte der Ostsee. Ann. Acad. Sci. Fennicae A III 51, 522 pp.

Schnitzer, M. and Skinner, S. I. M. (1968) Alkali versus acid extraction of soil organic matter. Soil Sci. Vol. 105, No 6.

Shepard, A. O. (1968) Ceramics for the Archaeologists. Carnegie Inst. of Wash. Publ. 609.
Sokal, R. R. and Sneath, W. (1963) Principles of Numerical Taxonomy. London-San Francisco. Stos-Fertner, Z., Hedges, R. E. M. and Evely, R. D. G. (1979) The application of the XRF-XRD method to analysis of the pigments of Minoan painted pottery. Archaeom. 21, Part 2.

Tite, M. S. (1972) Methods of Physical Examination in Archaeology. Seminar Press London and New York.

Äyräpää (Europaeus), A. (1925) Kivikauden kokoelmain kasvu vuosina 1920-23. Suomen Museo 1925. Helsinki.

Äyräpää, A. (1930) Die relative Chronologie der steinzeitlichen Keramik in Finnland I-II. Acta Archaeologica I. København.

- (1955) Den yngre stenålderns kronologi i Finland och Sverige. Finskt Museum 1955. Helsingfors.

Manuscript received, March 11, 1980

\section{Appendix \\ The sample vessels \\ Stylistic description}

Ka II: 1. Group A. Vessel 61. (Fig. 1). KM 17075: $329,335,336,359,376,378$. Identifiable outer surface $150 \mathrm{~cm}^{2}$. Approximate diameter at mouth over $20 \mathrm{~cm}$. Decorative elements: short fine comb stamps rows, rows of pits, chevronlike zig-zag figures bordered and hatched with comb stamp impressions. Corresponds to Äyräpää's definition of $\mathrm{Ka}$ »Hochstil».

Vessel 42. (Fig. 1). KMI 17075: 153, 161. Identifiable outer surface $24 \mathrm{~cm}^{2}$. Approximate diameter at mouth over $20 \mathrm{~cm}$. Decorative elements: short comb stamps, pits. Motifs: rows of pits, geometric designs (cf. vessel 61) bordered and hatched with comb stamp impressions.

Group B. Vessel 93. (Fig. 2). KM 17075: 34, 409. Identifiable outer surface $15 \mathrm{~cm}^{2}$. Approximate diameter at mouth over $20 \mathrm{~cm}$. Decorative elements: short thick comb stamps, pits, finger impressions. Motifs: rows of comb stamps, rows of pits, retangular fields of comb stamps.

Vessel 37. (Fig. 2). KM 17075: 249, 250, 252, 323, 329. Identifiable outer surface over $600 \mathrm{~cm}^{2}$. Approximate diameter at mouth over $20 \mathrm{~cm}$. Decorative elements: short fine comb stamps, pits of oblong form. Motifs: rows of comb stamps, rows of pits, lozenge-like fields of comb stamps in rows. Repaired with pitch.
Group C. Vessel 19. (Fig. 3). KM 17075: 143, 152, $244,254,262,263$. Identifiable outer surface $200 \mathrm{~cm}^{2}$. Approximate diameter at mouth over $20 \mathrm{~cm}$. Decorative elements: Fine and thick short comb stamps, two-part stamps resembling fish vertebrate impressions, pits. Motifs: rows of comb stamps, rows of pits, groups of twopart stamps and pits in rows. Indentation on top of rim.

Vessel 57. (Fig. 3). KM 17075: 324, 327. Identifiable outer surface $300 \mathrm{~cm}^{2}$. Approximate diameter at mouth over $20 \mathrm{~cm}$. Decorative elements: long and short fine comb stamps pits. Motifs: rows of comb stamps, rows of pits, solitary row of lozenge-like fields of comb stamps.

„Other» Vessel 71. (Fig. 5). KM 17075: 359, 367, 378, 379, 385. Approximate diameter at mouth over $20 \mathrm{~cm}$. Identifiable outer surface $200 \mathrm{~cm}^{2}$. Decorative elements: long impressions possibly executed with a comb stamp, indentations visible in places, pits. Motifs: rows of above impressions, rows of pits, groups of three pits forming triangular design.

Ka III: 1. Vessel 13. (Fig. 4). KM 17075: 115, 116, 205. Approximate diameter at mouth over 20 $\mathrm{cm}$. Identifiable outer surface $450 \mathrm{~cm}^{2}$. Decorative elements: large and small pits, finger 
impressions. Motifs: row of finger impressions on edge of rim, rows of pits.

Vessel 74. (Fig. 4). KM 17075: 365, 367. Diameter at mouth $10-20 \mathrm{~cm}$. Identifiable outer surface $40 \mathrm{~cm}^{2}$. Decorative elements: large and small pits. Motifs: vertical rows of interspaced large and small pits.
Pit and comb ware. Vessel 14. (Fig. 5). KM 17075: $124,125,132,134,160,223,350$. Diameter at mouth over $20 \mathrm{~cm}$. Identifiable outer surface over $200 \mathrm{~cm}^{2}$. Decorative elements: short and thick comb stamps, pits. Motifs: rows of comb stamps, rows of pits placed close to another, groups of several pits forming triangular designs. 